\title{
THE USE OF AN INERTER FOR BASE-ISOLATION SYSTEM IN A SINGLE- DEGREE-OF-FREEDOM STRUCTURE
}

\author{
Predaricka Deastra $^{1}$ \\ ${ }^{1}$ Former PhD student at Dynamics Research Group, The University of Sheffield, United \\ Kingdom \\ Email: pdeastra1@sheffield.ac.uk
}

\begin{abstract}
ABSTRAK
Makalah ini menyajikan kinerja seismik dari struktur satu derajat kebebasan (SDOF) yang dilengkapi dengan sistem isolasi dasar (BIS). BIS umumnya menggunakan bahan karet untuk memberikan fleksibilitas lateral untuk meminimalkan energi yang ditransmisikan, yang disebabkan oleh gerakan tanah ke struktur. Konsepnya adalah untuk menurunkan frekuensi alami struktural sedemikian rupa, agar terjadi penurunan jauh di bawah frekuensi dominan dari sebagian besar gempa bumi. Efek serupa juga dapat dicapai dengan menggunakan perangkat yang disebut inerter, yaitu sebuah perangkat dengan dua terminal dimana gaya yang dihasilkan sebanding dengan percepatan relatif antara dua terminalnya. Alih-alih mengurangi kekakuan, inerter memperkuat massa teoritis struktur tanpa meningkatkan massa fisiknya secara signifikan. Hal ini karena, tergantung pada mekanisme alatnya, sebuah inerter mampu menghasilkan inertance (rasio konstan antara gaya yang dihasilkan dan percepatan relatif antara kedua terminal inerter) beberapa kali lebih tinggi dari massa fisiknya. Dalam makalah ini, efektivitas inerter yang digunakan sebagai BIS dibandingkan dengan konsep BIS yang umum. Hasilnya menunjukkan bahwa BIS dengan inerter, untuk frekuensi alami yang sama, memiliki rentang frekuensi yang lebih panjang di sekitar frekuensi alami struktur dimana respon struktur yang terjadi lebih rendah. Selanjutnya, salah satu masalah utama pada struktur dengan BIS adalah gempa dengan periode panjang yang dapat bersesuaian dengan periode struktur dengan BIS sehingga dapat menimbulkan resonansi. Dalam makalah ini, disajikan dalam analisis domain waktu, bahwa struktur dengan inerter memiliki respon yang lebih rendah dibandingkan dengan struktur dengan BIS tradisional ketika mengalami gerakan tanah gempa dengan periode panjang.
\end{abstract}

Kata kunci: Sistem isolasi dasar, inertansi, inerter, resonansi

\section{INTRODUCTION}

Base isolation has long been one of the wellestablished methods for mitigating earthquake-induced vibration in building structures. The principle of base isolation is reducing the first fundamental frequency of the host structure such that the upper structure can be isolated from its foundation. In other words, the ground-to-structure vibration transmissibility is reduced. This can be achieved, for example, by a flexible material installed between the upper structure and its foundation.
Many base isolation systems have been studied, for example, roller bearing base isolation (Kelly, 1993 and Robinson, 1982), friction bearing base isolation (Mokha, Constantinou, Reinhorn, \& Zayas, 1991 and Wang, Teng, \& Chung, 2001), and rubber bearing base isolation (Lee, Ou, Niu, Song, \& Liang, 2010 and Ortiz, Magluta, \& Roitman, 2015).

On the other hand, the inerter is a twoterminal device generating forces proportional to the relative acceleration between its two terminals. Mathematically, 
the force generated by an inerter can be expressed as

$$
f_{b}=b\left(a_{1}-a_{2}\right)
$$

where $a_{1}$ and $a_{2}$ are the acceleration at the inerter's Terminal 1 and 2, respectively, and $b$ is the constant ratio between the generated force and the relative acceleration measured in kilogram.

The term inerter was firstly used by Smith (2002) and was revealed in the early 2000s. It was first used as a secret element in Formula 1 racing cars. Since then, the application of inerters has been proposed widely for many purposes, for example, for building structures (Deastra, Wagg, \& Sims, 2018), car suspension (Soong, Ramli, \& Mahadi, 2014), and aircraft landing gear (Dong, Liu, \& Chen, 2015).

In earthquake engineering community, the inerter has achieved a special attention. This is because, depending on the inertance generating mechanism, inerters are capable of generating inertance several times higher than their physical mass. For example, the inerter built in the University of Cambridge (Papageorgiou, Houghton, \& Smith, 2009) can generate inertance up to $700 \mathrm{~kg}$ with its physical mass of only $3.5 \mathrm{~kg}$. This important feature has attracted many researchers to further study the benefit of using inerters for various applications. In the earthquake engineering community, inerters have been proposed to replace the secondary mass of the tuned-mass-damper (TMD), which is called as tuned-inerter-damper (TID) (Lazar, Neild, \& Wagg, 2014), or as an additional element to the TMD, known as tuned-mass-damperinerter (TMDI) (Marian \& Giaralis, 2014).

A single inerter can reduce the fundamental frequency of an SDOF structure, as discussed in (Chen et al., 2014). It is because it works as a mass amplifier without significantly increasing the structure's total physical mass. Therefore, theoretically, it works in the same way as base isolation. However, instead of providing flexibility on the first story to reduce the structural natural frequency, the inerter amplifies the structural mass. In this paper, the seismic performance of a traditional base-isolated SDOF structure is compared to an SDOF structure equipped with a single inerter. Furthermore, the effect of long period earthquakes will also be discussed in the time domain.

\section{STRUCTURAL SYSTEM}

The SDOF structure shown in Figure 1 is used as a benchmark in this study. The displacement of the floor is assumed to be $x$, where $m$ and $k$ are the mass and stiffness of the structure. The natural damping of the structure is neglected.

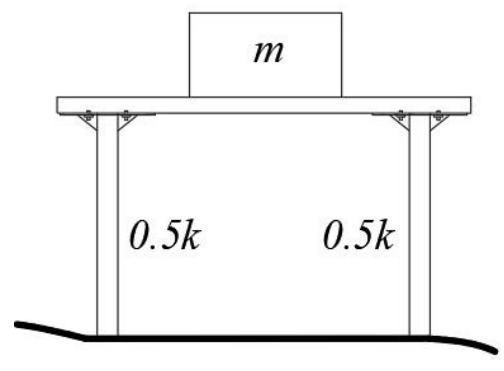

Figure 1. SDOF structure

The structure is then simulated with the ground motion input, $g$. The structure's response with a traditional BIS is compared with an inerter base isolation. Figure 2 illustrates the schematic of both structures, where $m_{b}=$ the isolation story mass of the structure required for installing the base isolation system.

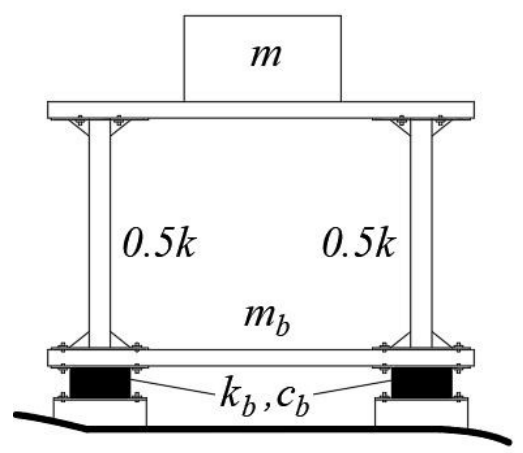

(a) 


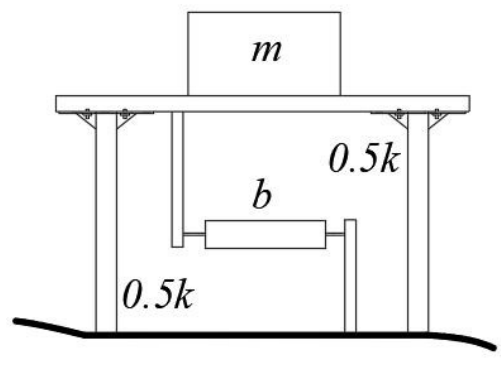

(b)

Figure 2. SDOF structure equipped with (a) Traditional BIS (b) A single inerter.

As shown in Figure 2(a), the traditional base isolation is modeled as a parallel springdashpot with properties of $k_{b}$ and $c_{b}$. Both represent the lateral stiffness of the isolator and the natural damping of the isolator, respectively. The structure performance of the base-isolated structure is compared to the SDOF structure equipped with an inerter, as shown in Figure 2(b). Here, a single inerter with inertance $b$ is installed between the ground and the floor. Hence, the force generated by the inerter is proportional to the relative acceleration between the ground and the floor.

The ground-to-floor transmissibility of the structure with an inerter in absolute coordinates can be expressed in the Laplace domain as follows:

$$
X / G=\left(b s^{2}+k\right) /\left((m+b) s^{2}+k\right)
$$

where $X$ and $G$ are the Laplace transform of the floor displacement $x$ and the ground motion $g$, respectively. $m$ and $k$ are the mass and stiffness of the structure. $s$ represents the Laplace transform variable defined as $s=j \omega, j=\sqrt{-1}$, and $\omega$ is the excitation frequency in $\mathrm{rad} / \mathrm{s}$. While for the structure with a BIS shown in Figure 2(a), the ground-to-top story transmissibility can be expressed as

$$
X / G=\left[M s^{2}+C s+K\right]^{-1} F
$$

where $\boldsymbol{X}$ and $\mathbf{G}$ are the Laplace transform of the displacement matrix and ground motion, respectively. $\boldsymbol{M}, \boldsymbol{C}$, and $\boldsymbol{K}$ are mass, damping and stiffness matrices, respectively, and are defined as $\boldsymbol{M}=\left[\begin{array}{cc}m & 0 \\ 0 & m_{b}\end{array}\right], \quad \boldsymbol{C}=$ $\left[\begin{array}{cc}0 & 0 \\ 0 & c_{b}\end{array}\right], \boldsymbol{K}=\left[\begin{array}{cc}k & -k \\ -k & k+k_{b}\end{array}\right] . \boldsymbol{F}$ is a matrix of ground motion coefficient defined as $\left[\begin{array}{c}0 \\ k_{b}+c_{b} s\end{array}\right]$.

\section{RESULTS AND DISCUSSION}

\section{Frequency-domain analysis}

The benchmark SDOF structure shown in Figure 1 has mass $m=7000 \mathrm{~kg}$, and $k=$ $6280.89 \mathrm{kN} / \mathrm{m}$. To mitigate the ground motion-induced vibration in the structure, two strategies are proposed and compared. The first strategy provides a traditional BIS between the structure and the foundation, as shown in Figure 2(a). The second strategy has a single inerter element connecting the structural mass and the ground, as shown in Figure 2(b).

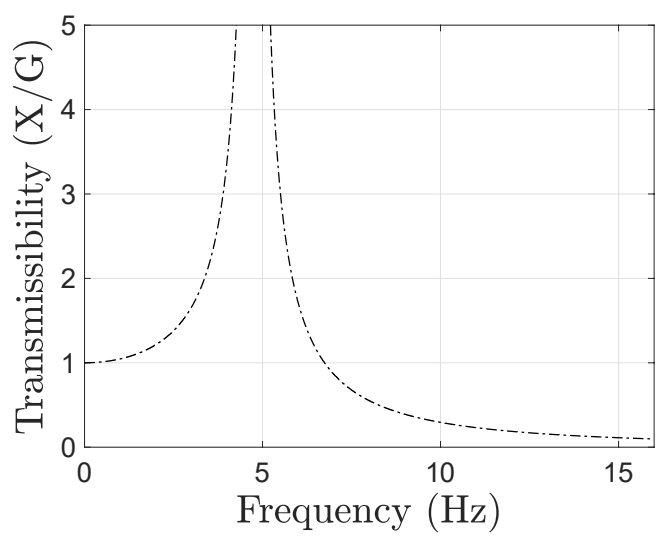

Figure 3. Transmissibility graph of the uncontrolled SDOF structure

Based on the given parameters, the groundto-floor transmissibility of the SDOF structure is depicted in Figure 3. As shown in Figure 3, the fundamental frequency of the structure is around $5 \mathrm{~Hz}$, which is around the 
predominant frequency of most earthquakes. By adding a BIS with $k_{b}, c_{b}$ and $m_{b}$ are 700 $\mathrm{kN} / \mathrm{m}, 3 \mathrm{kNs} / \mathrm{m}$, and $1000 \mathrm{~kg}$, respectively, the natural frequency of the structure can be significantly reduced to be less than $2 \mathrm{~Hz}$ as shown in Figure 4.

It should be noted that because the structure's natural damping is neglected, the response amplitude of the structure around the first resonance is very high.

The SDOF structure equipped with an inerter can achieve a similar level of isolation as in the case of a structure with a BIS. As previously mentioned, a single inerter can reduce the natural frequency of a host structure by amplifying the theoretical mass without significantly increasing the structure's actual mass.

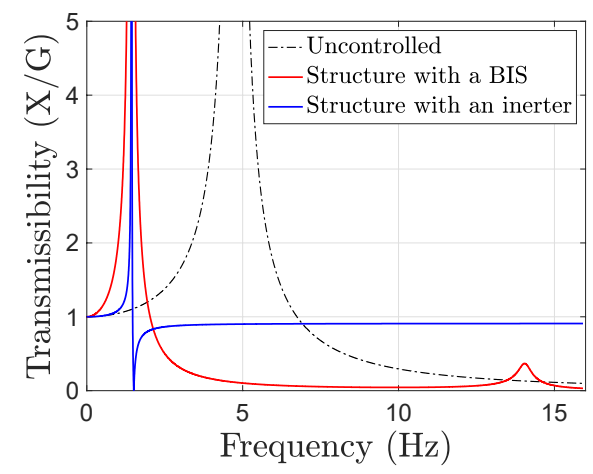

Figure 4. Transmissibility graph of the three considered structures

The transmissibility graph of the SDOF structure equipped with the inerter is also presented in Figure 4. To achieve a similar level of natural frequency, an inertance of 70 tons is required, which is seven times higher than the structural mass $m$. Moreover, the inerter enhances the structural performance by reducing its natural frequency such that it behaves as a base-isolated structure (Figure 4). Although the structure's response above the resonance is higher than the base-isolated structure, it is still below 1 , which means it is still isolated. Another difference observed is that the structure with a BIS has a second resonance around $14 \mathrm{~Hz}$. Therefore, adding a BIS into the structure means adding another degree of freedom to the structure.

From Figure 4, it can be concluded that both strategies can effectively reduce the first fundamental frequency of the benchmark SDOF structure. As a result, the area around $5 \mathrm{~Hz}$ (the first vibration mode of the benchmark SDOF structure) is now well isolated. The first strategy is achieved by providing a BIS with a very flexible lateral stiffness. The second strategy relies on a single inerter with its inertance value of 70 ton. Although this value is far higher than the structural mass $m$, however, depending on the inertance generating mechanism, this value can be easily achieved with a small device. Comparing the structural response around the first resonance, the response of the SDOF structure with the inerter is narrower. As a result, it has a lower response than the base-isolated structure for a range of excitation frequency around the resonance $(0 \mathrm{~Hz}$ to $2 \mathrm{~Hz})$.

To further investigate the structural performance comparison between both strategies, a time-domain analysis will be presented when the structures are subjected to earthquake ground motion.

\section{Time-domain analysis}

Resonance has been one of the main problems in a base-isolated structure when subjected to a long-period earthquake. It is because long-period earthquakes have lower predominant frequency of excitation. This section will compare the structure's response with both strategies when subjected to a longperiod earthquake.

The equation of motion of the benchmark structure in the time domain can be expressed as

$$
m \ddot{x}+k(x-g)=0
$$




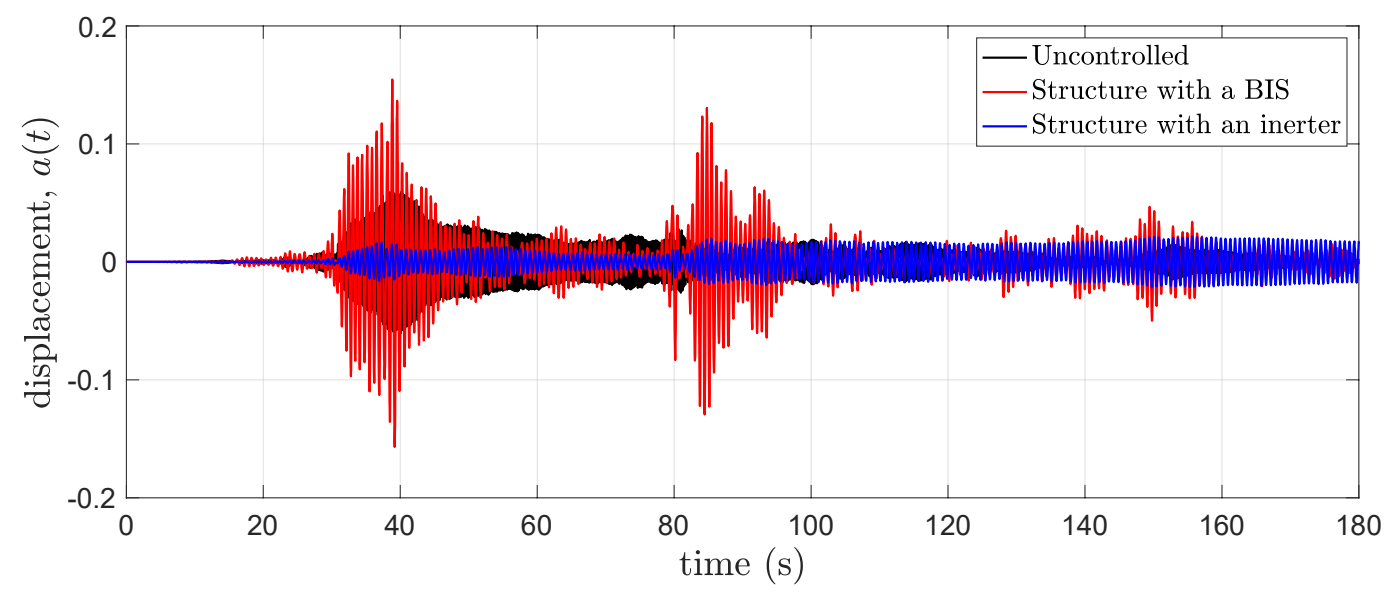

Figure 5. Response of the structures subjected to Tohoku earthquake ground motion

here [ " ] represents the second derivative with respect to time.

For the first strategy, the SDOF structure is equipped with a BIS. The equation of motion of the structure can be written as

$$
\left\{\begin{array}{c}
m \ddot{x}+k\left(x-x_{b}\right)=0 \\
m_{b} \ddot{x}_{b}+\left(k_{b}+k\right) x_{b}-k x+c_{b} \dot{x}_{b} \\
=k_{b} g+c_{b} \dot{g}
\end{array}\right.
$$

The second strategy employs an inerter connecting the floor and the ground. The equation of motion of the structure in the time domain can be expressed as

$$
(m+b) \ddot{x}+k x=k g+b \ddot{g}
$$

The equation of motion of the benchmark structure can also be expressed in a relative coordinate system as follow:

$$
m \ddot{a}+k a=-m \ddot{g}
$$

Note: $a=x-g$. For the BIS structure, the equation of motion becomes

$$
\left\{\begin{array}{c}
m \ddot{a}+k\left(a-a_{b}\right)=-m \ddot{g} \\
m_{b} \ddot{a}_{b}+k_{b} a_{b}+c_{b} \dot{a}_{b}-k\left(a-a_{b}\right) \\
=-m \ddot{g}
\end{array}\right.
$$

and for the structure with the inerter, the equation of motion in a relative coordinate system becomes

$$
(m+b) \ddot{a}+k a=-m \ddot{g}
$$

Figure 5 shows the seismic response of the three considered structures (uncontrolled (benchmark), structure with a BIS, structure with the inerter) when subjected to a Tohoku earthquake that took place in Japan on March 11th, 2011. The predominant frequency of the earthquake is between $1-3 \mathrm{~Hz}$, as presented in (Deastra, Wagg, \& Sims, 2021). This frequency range coincides with the natural frequency of the structure with a BIS and with the inerter. Therefore, the structural response of the uncontrolled structure is 
expected to be lower than the structure's response with both control strategies. It should be noted that the natural damping of the benchmark structure is no longer kept null; a viscous damping coefficient of $1 \mathrm{kNs} / \mathrm{m}$ is added to the structure.

As shown in Figure 5, the structure's response with a traditional BIS is larger than the uncontrolled structure's response due to resonance. On the other hand, structure's response with an inerter has the lowest response among all of the considered cases.

\section{CONCLUSION}

This paper presents the use of an inerter for mitigating earthquake-induced vibration in an SDOF structure. An SDOF benchmark structure was chosen with a fixed base. Two control strategies were proposed and compared: (1) a traditional BIS and (2) an inerter.

In the first strategy, a BIS is installed between the upper SDOF structure and the ground. The BIS is modeled as a parallel spring and viscous damping representing the BIS's lateral stiffness and natural damping.

In the second strategy, the inerter is installed between the story $m$ and the ground. The force generated by the inerter is proportional to the relative acceleration between the story and the ground.

A BIS isolates the upper structure from its foundation by reducing the lateral stiffness of the isolated floor using a flexible material, such as rubber. The same effect can also be achieved by increasing the structural mass of the structure. However, the increase of mass could increase the design of structural dimensions, such as columns and beams.

An inerter is capable of generating inertance several times higher than its physical mass, depending on its inertance generating mechanism. Therefore, using the inerter has a similar effect to using a traditional BIS, reducing the structural natural frequency.
This paper discusses the structural performance comparison of an SDOF structure when equipped with a BIS and the inerter. The result shows that for the same targeted natural frequency, the structural response around resonance for the SDOF structure with the inerter is narrower than the BIS has. Therefore, more regions in the frequency response around resonance where the inerter is superior to the BIS.

One of the main problems in a traditional BIS is resonance due to long-period earthquakeinduced vibration. The predominantfrequency of a long-period earthquake could coincide with the natural frequency of a baseisolated structure.

In this paper, a Tohoku earthquake was selected as a ground motion. The predominant frequency of the earthquake coincides with the natural frequency of the SDOF structure equipped with a BIS and of the SDOF structure equipped with the inerter, but away from the natural frequency of the benchmark SDOF structure. The timedomain analysis results show that the structure's response with the inerter is lower than that of the SDOF structure equipped with a traditional BIS. This paper provides new insight into the effectiveness of the inerter in SDOF structures to mitigate earthquake-induced vibrations.

\section{REFERENCES}

Chen M. Z. Q. et al. (2014). Influence of inerter on natural frequencies of vibration systems. Journal of Sound and Vibration 333.7, 1874-1887.

Deastra, P., Wagg, D. J., \& Sims, N. D. (2018). The effect of a tuned-inerterdamper on the seismic response of base-isolated structures. 16th European Conference on Earthquake Engineering. Thessaloniki.

Deastra, P., Wagg, D. J., \& Sims, N. D. (2021). Using a Tuned-InertoViscous-Hysteretic-Damper 
(TIVhD) for vibration suppression in multi-storey building structures. IOP Conference Series: Earth and Environmental Science. IOP Publishing.

Dong, X., Liu, Y., \& Chen, M. Z. (2015). Application of inerter to aircraft landing gear suspension. 34th Chinese Control Conference (CCC). IEEE.

Kelly, J. M. (1993). Earthquake-resistant design with rubber. Vol. 7.

Lazar, I., Neild, S., \& Wagg, D. (2014). Using an inerter-based device for structural vibration suppression. Earthquake Engineering \& Structural Dynamics, vol. 43 , no. 8 , pp. 1129-1147.

Lee, G. C., Ou, Y. C., Niu, T., Song, J., \& Liang, Z. (2010). Characterization of a roller seismic isolation bearing with supplemental energy dissipation for highway bridges. Journal of Structural Engineering, vol. 136, no. 5, pp. 502-510.

Marian, L., \& Giaralis, A. (2014). Optimal design of a novel tuned massdamper-inerter (TMDI) passive vibration control configuration for stochastically support-excited structural systems. Probabilistic Engineering Mechanics 38, 156-164.

Mokha, A., Constantinou, M., Reinhorn, A., \& Zayas, V. A. (1991). Experimental study of friction-pendulum isolation system. Journal of Structural Engineering, vol. 117, no. 4, pp. 1201-1217.

Ortiz, N. A., Magluta, C., \& Roitman, N. (2015). Numerical and experimental studies of a building with roller seismic isolation bearings. Structural Engineering and Mechanics, vol. 54, no. 3, pp. 475-489.
Papageorgiou, C., Houghton, N. E., \& Smith, M. C. (2009). Experimental testing and analysis of inerter devices. $J$. Dyn. Syst. Meas. Contr.

Robinson, W. H. (1982). Lead-rubber hysteretic bearings suitable for protecting structures during earthquakes. Earthquake Engineering \& Structural Dynamics, vol. 10 , no. 4, pp. 593-604.

Smith, M. C. (2002). Synthesis of mechanical networks: The inerter. IEEE Transactions on Automatic Control, vol. 47, no. 10, pp. 1648-1662.

Soong, M. F., Ramli, R., \& Mahadi, W. N. (2014). Vehicle suspensions with parallel inerter: Effectiveness in improving vibration isolation. Journal of Vibroengineering, 256265.

Wang, Y. P., Teng, M. C., \& Chung, K. W. (2001). Seismic isolation of rigid cylindrical tanks using friction pendulum bearings. Earthquake engineering \& structural dynamics, vol. 30, no. 7, pp. 1083-1099. 